УДК 378.1.013.83: [339.923:016.1€С]

DOI: https://doi.org/10.35387/od.2(20).2021.31-40

Дернова Майя Григорівна доктор педагогічних наук, доцент, профресор кафредри автоматизації та інфрормаційних систем, профресор кафедри перекладу Кременчуцького національного університету імені Михайла Остроградського
Dernova Maiia - Doctor of Pedagogical Sciences, Docent, Professor of the Automation and Information Systems Department, Professor of the Translation Department of the Kremenchuk Mykhailo Ostrohradskyi National Universit

ORCID iD: http://orcid.org/0000-0003-4545-5247

E-mail:maya.dernova@ukr.net

\title{
ФІНАНСОВІ ІНСТРУМЕНТИ ПІДТРИМКИ НАВЧАННЯ ДОРОСЛИХ В ЄВРОПЕЙСЬКИХ ЗАКЛАДАХ ВИЩОЇ ОСВІТИ
}

Анотація. У статті представлено результати аналізу законодавчих актів національного та регіонального рівнів щодо фрінансових інструментів стимулювання навчання дорослих у ЗВО досліджуваних європейських країн. Визначено, що національна і регіональна політика щодо залучення дорослих до навчання у закладах вищої освіти Франції, ФРН, Італії, Великобританії та Нідерландів спрямована на розширення участі дорослих у вищій освіті задля підвищення рівня працевлаштування, конкурентоспроможності та сталого економічного розвитку. Водночас з'ясовано, що досліджувані країни надають фрінансову підтримку дорослим для здобуття вищої освіти у різній мірі, що безпосередньо впливає на кількість дорослих у вищій освіті цих країн. Так, виявлено, що у Франції, ФРН і Нідерландах спостерігається тенденція до збільшення дорослих, які вступають до ЗВО (ФРН - 922611 осіб у 2018 році проти 698506 - у 2010 році; Франція - 271288 осіб у 2018 році проти 202727 у 2010 році; Нідерланди - 153417 осіб у 2018 році проти 96618 - у 2010 році), водночас у Великобританії та Італії показники свідчать про тенденцію до зменшення дорослих у вищій освіті (Великобританія - 275668 чоловік у 2018 році проти 314190 - у 2010 році; Італія - 376879 чоловік у 2018 році проти 451837 - у 2013 році). На підставі аналізу фрінансових інструментів підтримки дорослих щодо навчання у ЗВО у досліджуваних європейських країнах визначено, що Франція $і$ ФРН вирізняються розвиненою $і$ усталеною системою державних і регіональних пільг для дорослого населення щодо участі у вищій освіті; у Нідерландах заслуговує на увагу триваючий експеримент фрінансової підтримки та гнучкої оплати навчання у ЗВО, який позитивно впливає на збільшення кількості дорослих, які бажають отримати вищу освіту.

Ключові слова: освіта і навчання дорослих; вища освіта; дорослі студенти; європейський простір вищої освіти; фрінансування навчання дорослих. 


\section{Dernova Maiia}

\section{FINANCIAL SUPPORT FOR ADULT LEARNING IN EUROPEAN HIGHER EDUCATION INSTITUTIONS}

Abstract. The article presents the results of the analysis of national and regional levels legislative acts on financial support for adults who enter HEI in the studied European countries. It has been found out that the national and regional policy on adult involvement in higher education in France, Germany, Italy, Great Britain and the Netherlands is aimed at widening the participation of adults in higher education in order to increase their employment, competitiveness and sustainable economic development of the country. At the same time, it has been revealed that the European countries provide financial support to adults for their higher education studies in different ways, which directly affects the number of adults in higher education in these countries. It has been found out that in France, Germany and the Netherlands there is a tendency for increasing the number of adults entering HEls (Germany - 922,611 adults in 2018 against 698506 - in 2010; France - 271288 adults in 2018 against 202727 - in 2010; The Netherlands - 153417 adults in 2018 against 96618 - in 2010), while in the UK and Italy the data shows a downward trend in adults in higher education (UK - 275668 adults in 2018 against 314190 - in 2010, Italy - 376879 adults in 2018 against 451837 - in 2013). Based on the analysis of financial support to adults for higher education studies in the European countries, it has been concluded that France and Germany have a developed and well-established system of state and regional benefits for adults in higher education; in the Netherlands, the ongoing experiment of financial support and flexible tuition fees in HEls is noteworthy, because it has a positive effect on increasing the number of adults seeking higher education.

Key words: adult education and training; higher education; adult students; European Higher Education Area; financial support for adults.

Постановка проблеми, її актуальність. Пов'язуючи навчання та потреби економічного світу, безперервне навчання у вищій школі надає можливість тим дорослим, хто рано розпочав професійне життя, отримати доступ до програм та дипломів вищої освіти. Безперервне навчання впродовж життя також дозволяє оптимізувати час навчання, беручи до уваги знання та ноу-хау кожної людини, ефективніше реагувати на потреби та очікування людей, компаній та суспільства.

Аналітичні прогнози показують, що потреба у вищій освіті для дорослих продовжує зростати (Cedefop, 2018, URL), що зумовлено зменшенням кількості молодих людей внаслідок демографічної ситуації у Європі. Це обумовлює необхідність особистісного і професійного розвитку дорослих впродовж життя для задоволення попиту на висококваліфіковану робочу силу й економічне зростання європейських країн. Задовольнити існуючу потребу стає можливим за допомогою створення умов для поєднання навчання з роботою та іншими зобов'язаннями дорослих та надання освітньої пропозиції, яка б оптимально відповідала побажанням та потребам цієї цільової групи.

Аналіз актуальнихх досліджень і публікацій. У зарубіжному 
науковому просторі активно досліджується проблема професійної підготовки дорослих у закладах вищої освіти. Значний інтерес становлять результати наукових розвідок зарубіжних учених у сфері освіти дорослих, зокрема С. Брукфілда, Г. Кофессора, М. Делена, Дж. Девенпорта, Г. Діна, М. Дерріка, К. Доллхаузена, Дж. Дрепера, Д. Фора, П. Фрейре, Г. Гроу, Р. Хіємстри, Р. Брокетта, К. Хоула, Р. Хатчінса, Дж. Джарвіса, Л. Кесворма, С. Мерріам, М. Ноулза, К. Неппер, Д. Колба, Д. Літтла, У. Літтлвуд, Р. Каффрарелли та ін.

Серед вітчизняних вчених цю проблему активно розробляють О. Аніщенко, С. Архипова, С. Бабушко, О. Баніт, А. Боярська-Хоменко, О. Дубасенюк, Н. Литвинова, І. Литовченко, Л. Лук'янова, Н. Ничкало, О. Огієнко, В. Олійник, С. Прийма, Т. Протасова, С. Саган, Л. Сігаєва, О. Теренко, Л. Тимчук та ін.

Мета статті. Контекст нашого дослідження потребує поглибленого аналізу фінансових інструментів сприяння участі дорослих у вищій освіті на національному і регіональному рівнях у Франції, ФРН, Італії, Великобританії та Нідерландах.

Виклад основного матеріалу дослідження. Слід зазначити, що у Франції безперервна освіта у ЗВО спрямована на дорослих людей (службовців, пошукувачів роботи, вільнонайманих тощо), які перервали навчання та бажають здобути або розвинути кваліфікацію, збагатити професійний досвід; роботодавців, які бажають розвивати навички своїх працівників. У ході дослідження нами також з'ясовано, що у Франції навчання дорослих у ЗВО всебічно підтримується на державному рівні і регулюється Законом про свободу вибору професійного майбутнього (LOI $\mathrm{n}^{\circ}$ 2018-771 du 5 septembre 2018 pour la liberté de choisir son avenir professionnel (1), 2018, URL).

Так, з 1 січня 2015 року упроваджено особистий навчальний рахунок (Le compte personnel de formation, CPF), метою якого є підвищення рівня кваліфікації кожної дорослої людини та забезпечення її професійної кар'єри. Як новий засіб доступу до навчання, особистий навчальний рахунок може використовуватись дорослим, який працює, протягом усього його професійного життя, починаючи з 16 років і закінчуючи пенсією (Le compte personnel de formation (C.P.F.), 2020, URL).

Особистий навчальний рахунок - це рахунок у євро (з 1 січня 2019 року), який дозволяє будь-якому працівнику чи пошукувачеві роботи пройти навчальний курс за власним вибором, щоб сприяти його підтримці працездатності та забезпеченню професійної кар'єри (Ministere du Travail, de l'Emploi et de l'Insertion, 2020a, URL).

Іншими інструментами державної підтримки участі дорослих у вищій освіті Франції є індивідуальна навчальна відпустка (Congé individuel de formation, CIF), яка дозволяє користуватися одним роком оплачуваної відпустки для денної форми навчання (або 2 років заочної в межах 1200 годин) та фрінансування від регіональної ради (Financement émanant d'un Conseil régional), яке працівники можуть отримати для проходження навчання у ЗBO поза робочим часом (наприклад, DAEU - диплом про 
доступ до університетських студій або дистанційне навчання).

На рівні роботодавця теж $€$ усталений інструмент підтримки навчання дорослих, зокрема план розвитку навичок (Le plan de développement des compétences), який об'єднує усі навчальні заходи, реалізовані в рамках політики управління персоналом компанії, включаючи визнання попереднього навчання й досвіду. Дії плану навчання в основному спрямовані на адаптацію працівника до змін на робочому місці, а також на розвиток його навичок. Цей навчальний план фінансується роботодавцем (Ministere du Travail, de l'Emploi et de l'Insertion, 2020b, URL)

Слід підкреслити, що послуги безперервної освіти, присутні у кожному ЗВО Франції, які пропонують підтримку повернення до навчання (прийом, інформація та поради); допомогу у побудові професійного плану та індивідуального навчального курсу; перевірку набутого досвіду з метою отримання диплому (La formation continue tout au long de la vie dans l'enseignement supérieur, 2020, URL).

Як засвідчують результати дослідження, у ФРН урядові організації передбачають дефіцит кваліфікованих робітників через демографічну ситуацію в країні, тому навчання дорослих впродовж життя має вирішальне значення для сталого розвитку німецького суспільства (Europäische Bildungsprogramme und lebenslanges Lernen in Deutschland, 2020, URL). Федеральний уряд підтримує подальше навчання за рахунок бонусу на освіту до 500 євро. Дорослі, які мають професійну кваліфікацію можуть подати заявку на підвищення гранту до 650 євро та 80 євро на місяць на книги. Участь у магістерських курсах фінансується федеральним урядом за допомогою програми позики на 675 євро на місяць для одиноких людей та до 1310 євро на місяць для одружених людей з двома дітьми.

Послуговуючись результатами пошуку, можна стверджувати, що у Німеччині існує фінансування для подальшого навчання майже кожного громадянина, а саме: для тих, хто шукає роботу, існує ваучер на освіту, для літніх людей - WeGebAU, для дорослих - грант на підвищення кваліфікації, для магістрів та кваліфікованих робітників (AufstiegsBAföG), а для працівників та самозайнятих - бонус за освіту. Наразі майже кожен другий громадянин працездатного віку у Німеччині бере участь у подальшому навчанні. Федеральний уряд та уряди земель підтримують бажання різних груп (вікових і соціальних) населення навчатися завдяки фрінансуванню (бонуси, путівки, гранти) та відпустці на навчання. Працівники, робітники та слухачі отримують свою регулярну зарплату під час навчальної відпустки. 32008 року працевлаштованим видаються сотні тисяч бонусних ваучерів на подальше навчання, пов'язане з роботою. Наразі спостерігається тенденція до зростання кількості виданих ваучерів на навчання (Europäische Bildungsprogramme und lebenslanges Lernen in Deutschland, 2020, URL).

За допомогою ваучера-преміум (Prämiengutscheine) на освіту держава сплачує половину внесків, максимум до 500 євро, а дорослий сплачує лише частину суми постачальнику навчання. Ощадний ваучер (Spargutschein) дозволяє достроково зняти збережений кредит відповідно 
без втрати надбавки до заощаджень працівників. До речі, можна фінансувати також так званий зовнішній іспит згідно із Законом про безперервне професійне навчання (Qualifizierung für die Arbeit von morgen, 2020, URL). Ваучер-преміум розрахований на людей, які працюють щонайменше 15 годин на тиждень або перебувають у відпустці для батьків чи по догляду та мають оподатковуваний дохід максимум 20000 євро. Ваучер-преміум можна отримати на календарний рік. Ваучери на освіту надають можливість брати участь у професійному навчанні, незалежно від роботодавця. Усі, хто хоче підготуватися до базової освіти, мовної та IT освіти, також можуть подати заявку на отримання ваучера. Ваучер на ocвimy (Bildungsgutschein) можна отримати від агенції з працевлаштування або центру вакансій для покриття витрат на подальше навчання з метою отримання роботи, запобігання звільненню та отримання потрібної кваліфікації (Förderung von Weiterbildung, 2020, URL)

Подальше навчання низькокваліфікованих і працевлаштованих літніх людей у компаніях (Weiterbildung Geringqualifizierter und beschäftigter älterer Arbeitnehmer in Unternehmen, WeGebAU) надається для працівників, які не мають професійної кваліфікації або не працювали за професією, яку вивчали, принаймні чотири роки. Залежно від віку, витрати на навчання частково або повністю покриваються та оплачуються державою.

Закцентуємо увагу, що нещодавно у ФРН прийнято Закон про сприяння професійному навчанню - Закон про сприяння підвищенню кваліфікації (AFBG) (Gesetz zur Förderung der beruflichen Aufstiegsfortbildung - Aufstiegsfortbildungsförderungsgesetz - (AFBG), 2020, URL), який врегульовує фрінансові механізми індивідуальної підтримки дорослих щодо участі у вищій професійній освіті для підвищення кваліфікації. На цю схему мають право кваліфіковані робітники та інші спеціалісти, які готуються до здобуття наукового ступеня магістра. Учасники отримують внесок у вартість подальшого навчання незалежно від їхнього доходу, а у випадку денного навчання - додатковий внесок у витрати на життя залежно від доходу. Одинокі громадяни отримують максимум 768 євро на місяць, одинокі батьки отримують максимум 1003 євро на місяць. Одружені учасники курсів з однією дитиною отримують максимум 1238 євро на місяць, а з двома дітьми - 1473 євро на місяць. Фінансування частково надається як грант, а частково як позика під низькі відсотки від Корпорації кредитування та реконструкції KfW.

Іншим федеральним інструментом підтримки навчання дорослих у ЗВО є стипендія на просування (Aufstiegsstipendium). Працівники можуть подати заявку на отримання гранту, що фінансується державою, для покриття витрат на освіту та навчання. Право на освіту та навчання включає всі види університетських студій. Програма орієнтована насамперед на тих, хто здобув вищу освітню кваліфікацію без навчання у 3ВО завдяки багаторічному досвіду, визнанню попереднього навчання й досвіду. Особи, які мають право на стипендію, отримують щомісячно 670 євро плюс 80 євро на книги. Крім того, надається пакет допомоги для дітей до 10 років (113 євро для першої дитини, 85 євро за кожну додаткову). 
Підтримка надається незалежно від заробітку. Студенти, які проходять позапрофесійне навчання, отримують 2000 євро на рік. Стипендія спочатку розраховується на 1 рік і може бути продовжена на наступний рік за результатами навчання. Хід навчання регулярно документується за допомогою моніторингу результатів (Aufstiegsstipendium, 2020, URL).

Заслуговує на увагу досвід фінансової підтримки навчання дорослих у ФРН на регіональному рівні. Мова йде про те, що багато федеральних земель у Німеччині стали важливими постачальниками фрінансування для надання різних типів ваучерів для подальшої освіти. Фінансові інструменти спрямовані частково лише на фрізичних осіб, частково - лише на підприємства, але частково - як на приватних осіб, так і на підприємства. Окрім схем ваучерів, федеральні землі можуть надавати співфрінансування для подальшого навчання.

Для дорослих, які навчаються у ЗВО у ФРН запроваджена податкова пільга, яка дає право на вирахування затрачених на навчання коштів з податку на доход (German income tax, 2020, URL).

В Італії працівники державного та приватного секторів можуть подати заявку на отримання індивідуальних ваучерів (принцип відшкодування). Міністерство праці та Міністерство економіки визначають щорічний розподіл ресурсів між регіонами. Регіони відповідають за здійснення заходу на своїх територіях. Допустимі витрати стосуються оновлення та підтримки професійних навичок робітників.

Італійські міжпрофесійні фонди надають можливість компаніям забезпечити навчання впродовж життя для своїх працівників. Міжпрофесійні фонди - це асоціативні органи, що підтримуються профспілками. Компанії виплачують міжпрофесійному фонду $0,30 \%$ за кожного робітника, а фонд, у свою чергу, гарантує повернення сплаченої суми для організації навчання своїх працівників (Che cos'è la formazione finanziata? 2020, URL).

Окрім того, в Італії існуть податкові пільги для тих працюючих дорослих, які навчаються у ЗВО, тобто витрати, пов'язані з навчанням, вираховуються із сплаченого податку. Фізична особа може подати податкову декларацію у розмірі $50 \%$ суми витрат, пов'язаних з навчанням, та $75 \%-50 \%$ витрат, пов'язаних із проживанням та харчуванням (Testo Unico delle Imposte sui Redditi, 2021, URL).

Вивчаючи фрінансові стимули дорослих до навчання у ЗВО у Великобританії, нами з'ясовано, що дорослі студенти можуть подати заявку на отримання грантів та стипендій, щоб допомогти оплатити курси та навчання (Grants and bursaries for adult learners, 2020, URL), або взяти позику у банка на оплату навчання у ЗВО (Mature students: university and funding, 2020, URL).

Закцентуємо на тому, що британський уряд у 2020 році прийняв рішення надати 2,5 мільярдів фрунтів для фрінансування профресійних курсів у коледжах для дорослих, які не мають кваліфікаційної освіти, щоб підвищити можливість їх працевлаштування (Personnel Today, 2020, URL).

Важливим поштовхом до активного вирішення проблеми участі 
дорослих у вищій освіті у Нідерландах стало помітне зменшення кількості представників цієї категорії студентів у ЗВО, що призвело до скорочення відсотку високоосвічених людей серед робочої сили (Flexibel hoger onderwijs voor volwassenen, 2014, URL). Відсоток студентів у віці 25 років і старше, які беруть участь у державній програмі бакалаврату, становить $6 \%$, що значно нижче середнього показника по ОЄСР (Strategische agenda hoger onderwijs en onderzoek: Houdbaar voor de toekomst. (2019). Тому уряд країни активно працює над створенням мотиваційних інструментів щодо розширення участі дорослих у вищій освіті, зокрема фінансування та кредитування попиту на вищу освіту для дорослих, створення гнучких шляхів навчання у закладах вищої освіти (Kamerbrief over resultaten verkenning vraagfinanciering en studiepuntbekostiging, 2019, URL).

На наше переконання, заслуговує на увагу експеримент з гнучким навчанням та державним фінансуванням у ЗВО, який розпочався у Нідерландах у вересні 2017 року. За умовами експерименту студентам денної форми навчання надається можливість сплачувати навчання пропорційно кількості кредитів, пов'язаних із курсами, які вони бажають пройти. Мета експерименту - дослідити, чи призводить така форма гнучкості до більш доступної освітньої пропозиції, меншого відсіву та більшого задоволення студентів (Evaluatie experiment flexstuderen, 2019, URL).

Фізичні особи отримують фінансову підтримку від держави для покриття витрат на навчання. Доступні лише обрані програми у вищій освіті без відриву від роботи. Вартість навчання не повинна перевищувати 3750 євро за 30 ECTS. Заочні програми можуть тривати 120 або 240 ECTS. На отримання гранту можуть претендувати особи, які не мають вищої освіти. Вони отримують ваучери 1250 євро за кожні 30 ECTS. Очікується, що решту плати покриватимуть особи та / або їх роботодавці. Дорослий має право отримати максимум 8 ваучерів (Kamerbrief over resultaten verkenning vraagfinanciering en studiepuntbekostiging, 2019, URL).

Основною цільовою групою нідерландського експерименту $\epsilon$ дорослі студенти, які хочуть або повинні поєднувати свою освіту з іншими зобов'язаннями. Експеримент триватиме до 2022-2023 навчального року включно. Проміжне оцінювання у грудні 2018 року засвідчило, що серед студентів існує достатній ентузіазм і що інтерес зростає. Жодних недоліків не виявлено, і фінансових причин зупинити експеримент не було.

Зроблено висновок, що участь та оплата за кредит є привабливою для дорослих студентів, які навчаються за сумісництвом та за дуальною формою навчання, оскільки вони часто не реалізують повного запрограмованого навчального навантаження на рік. Вважається, що застосування гнучкості оплати навчання у заочній та дуальній освіті може залучити більшу кількість дорослих до навчання у ЗВО.

Однак, як зазначається (Kamerbrief over resultaten verkenning vraagfinanciering en studiepuntbekostiging, 2019, URL), умовою ефективності гнучкого навчання $€$ активна діяльність закладів вищої освіти щодо модернізації змісту та форм навчання, щоб зробити освітні пропозиції та 
участь дорослих більш гнучкими та привабливими. Таким чином, застосування гнучких фрорм оплати і навчання у заочній та дуальній фрормі дає певні можливості розширення доступу до вищої освіти різним верствам населення.

У ході дослідження з'ясовано, що у Нідерландах для стимулювання дорослих людей піклуватися про власне працевлаштування, діє податкова пільга, яка частково компенсує їм витрати на навчання у ЗВО (Tax reduction for study costs or other education related expenditures: Netherlands, 2020, URL).

Висновки і перспективи подальших досліджень. Узагальнюючи результати наукового пошуку щодо фінансового стимулювання навчання дорослих у ЗВО Франції, ФРН, Італії, Великобританії та Нідерландів, можна зробити наступні висновки:

- національна політика усіх досліджуваних країн спрямована на розширення участі дорослих у вищій освіті задля підвищення рівня працевлаштування, конкурентоспроможності та сталого економічного розвитку, але не всі країни надають достатню фінансову підтримку дорослим для здобуття вищої освіти, що зумовлює кількість дорослих у цих країнах (Німеччина - 922611 осіб (2018 р.), 698506 осіб (2010р.); Франція 271288 осіб (2018р.), 202727 осіб (2010р.); Нідерланди - 153417 осіб (2018р.), 96618 осіб (2010р.); Великобританія - 275668 осіб (2018р.), 314190 осіб (2010 р.); Італія - 376879 осіб (2018 р.), 451837 осіб (2013 р.) (OECD. Stat. Enrolment by age (2010 -2018), 2019, URL);

- особливої уваги заслуговує система фінансових пільг для навчання дорослих у Франції та ФРН, оскільки саме ці країни вирізняються розвиненою й усталеною системою державних і регіональних фінансових інструментів стимулювання дорослого населення до участі у вищій освіті, а також експеримент з фінансової підтримки та гнучкої оплати навчання у ЗВО у Нідерландах, що останніми роками призвело до суттєвого зростання кількості дорослих осіб у вищій освіті цих країн.

Перспективним напрямом подальших досліджень уважаємо дослідження механізмів альтернативного доступу дорослих до вищої освіти в європейських країнах.

\section{References (translated and transliterated)}

Aufstiegsstipendium. (2020). Bundesministerium für Bildung und Forschung. URL: https://www.sbb-stipendien.de/aufstiegsstipendium

Cedefop. (2018). VET-in-Europe: Country Reports. URL: https://www.cedefop.europa.eu/en/publications-and-resources/countryreports/vet-in-europe-country-reports?page $=1$

Che cos'è la formazione finanziata? (2020). URL: https://www.zetaservice.com/it/blog/formazione-finanziata-e-finanziamentiper-la-formazione-del-personale-come-funziona.html

Europäische Bildungsprogramme und lebenslanges Lernen in Deutschland. (2020). URL: europaeische https://www.bundesregierung.de/breg-de/themen/bildung/ deutschland-437976 -bildungsprogramme-und-lebenslanges-lernen-in- 
Evaluatie experiment flexstuderen. (2019). URL: https://www.rijksoverheid.nl/ documenten/rapporten/2019/12/12/bijlage-2-evaluatie-experimentflexstuderen

Flexibel hoger onderwijs voor volwassenen. (2014). URL: https://www.scienceguide.nl/wp-content/uploads/2018/12/adviesrapportflexibilisering-hoger-onderwijs-1.pdf

Förderung von Weiterbildung. (2020). Bundesagentur für arbeit. URL: https://www.arbeitsagentur.de/karriere-und-weiterbildung/foerderungberufliche-weiterbildung

German income tax. (2020). URL: https://www.make-it-ingermany.com/en/jobs/taxes/income/

Gesetz zur Förderung der beruflichen Aufstiegsfortbildung Aufstiegsfortbildungsförderungsgesetz - (AFBG). (2020). URL: https://www.aufstiegs-bafoeg.de/de/das-gesetz-im-wortlaut-1712.html

Grants and bursaries for adult learners. (2020). URL: https://www.gov.uk/grantbursary-adult-learners

Kamerbrief over resultaten verkenning vraagfinanciering en studiepuntbekostiging. (2019). URL: https://www.rijksoverheid.nl/documenten/kamerstukken/ 2019/12/12/resultaten-verkenning-vraagfinanciering-enstudiepuntbekostiging

La formation continue tout au long de la vie dans l'enseignement supérieur. (2020). FORMATION CONTINUE TOUT AU LONG DE LA VIE. URL: https://www.enseignementsup-recherche.gouv.fr/cid21050/la-formationcontinue-universitaire.html

Le compte personnel de formation (C.P.F.). (2020). LA FORMATION CONTINUE DES ADULTES DANS L'ENSEIGNEMENT SUPÉRIEUR. URL: https://www.enseignementsup-recherche.gouv.fr/cid92095/le-comptepersonnel-de-formation-c.p.f.html

LOI $n^{\circ}$ 2018-771 du 5 septembre 2018 pour la liberté de choisir son avenir professionnel (1). (2018). URL: https://www.legifrance.gouv.fr/jorf/id/JORFTEXT000037367660/

Ministere du Travail, de l'Emploi et de l'Insertion. (2020a). Compte personnel de formation (CPF). URL: https://travail-emploi.gouv.fr/formationprofessionnelle/droit-a-la-formation-et-orientation-professionnelle/comptepersonnel-formation

Ministere du Travail, de l'Emploi et de l'Insertion. (2020b). Plan de développement des competences. URL: https://travail-emploi.gouv.fr/formationprofessionnelle/entreprise-et-formation/article/plan-de-developpement-descompetences

OECD. Stat. Enrolment by age (2010-2018). (2019). URL: https://stats.oecd.org/index.aspx?queryid=79474\#

Personnel Today. (2020). Government announces $£ 2.5 \mathrm{bn}$ lifelong learning package. URL: https://www.personneltoday.com/hr/lifetime-skills-guarantee/

Qualifizierung für die Arbeit von morgen. Gesetz zur beruflichen Weiterbildung. (2020). URL: https://www.bundesregierung.de/breg-de/aktuelles/beruflicheweiterbildung-1730354

Strategische agenda hoger onderwijs en onderzoek: Houdbaar voor de toekomst. (2019). Ministerie van Onderwijs, Cultuur en Wetenschap. URL: https://www.rijksoverheid.nl/documenten/rapporten/2019/12/02/bijlage-1- 
strategische-agenda-hoger-onderwijs-en-onderzoek-houdbaar-voor-detoekomst

Tax reduction for study costs or other education related expenditures: Netherlands. (2020). Financing adult learning database. URL: https://www.cedefop.europa.eu/en/publications-and-resources/tools/ financing-adult-learning-db/search/tax-reduction-study-costs-or-othereducation-related

Testo Unico delle Imposte sui Redditi. (2021). URL: https://www.altalex.com/documents/codici-altalex/2014/12/10/tuir-testounico-delle-imposte-sui-redditi

УДК 374.7.01:001.891

DOI: https://doi.org/10.35387/od.2(20).2021.40-50

$\begin{array}{lrl}\text { Лапаєнко Світлана } & \text { Lapaienko Svitlana - Candidate } \\ \text { Володимирівна - кандидат } & \text { of Pedagogical Sciences, Senior } \\ \text { педагогічних наук, старший } & \text { Research Fellow, Acting Head of } \\ \text { науковий співробітник, в.0. } & \text { the Department of Scientific } \\ \text { завідувача відділу наукового } & \text { Information and Analytical Support } \\ \text { інформаційно-аналітичного } & \text { of Education, V. O. Sukhomlynskyi } \\ \text { супроводу освіти Державної } & \text { State Scientific and Pedagogical } \\ \text { науково-педагогічної бібліотеки } & \text { Library of Ukraine } \\ \text { України } & \text { імені }\end{array}$

В. О. Сухомлинського

ORCID iD: http://orcid.org/0000-0002-0412-6618

E-mail: slapaenko@ukr.net

\section{ОСВІТА ДОРОСЛИХ У НАУКОВОМУ ДИСКУРСІ ВЧЕНИХ НАПН УКРАЇНИ}

Анотація. У статmі висвітлено основні наукові підходи вчених НАПН України щодо розвитку освіти дорослих (освіти впродовж життя) в Україні.

Охарактеризовано принцип людиноцентризму (В. Кремень), який в освіті дорослих передбачає сприяння розвитку особистості, самореалізації людини в особистому та професійному житті, підвищенню ї компетентності й конкурентоспроможності. Саме розвиток людини $\epsilon$ потужним чинником розвитку суспільства й економіки. Дотримання цього принципу забезпечує максимальне наближення освіти дорослих до освітньокультурних потреб і здібностей, життєвих планів особистості.

Обгрунтовано (Н. Ничкало), що створення відповідних умов для широкого залучення різних категорій дорослого населення до освіти впродовж життя, є ключовою умовою забезпечення конкурентоспроможності на ринку праці, що закономірно посилює роль освіти дорослих у розвитку сучасного суспільства на основі андрагогічно орієнтованих підходів до навчання в нових умовах цифрового суспільства.

З'ясовано (Л. Лук'янова), що на сучасному етапі розвитку освіти 